\title{
Jesus Prayer, the kernel of the Orthodox Christian spirituality
}

PhD. Alexandru-Corneliu ARION

Lecturer, Faculty of Theology and Sciences of Education, "Valahia" University of Târgovişte, ROMANIA

Email: alexcoarion@yahoo.co.uk

\begin{abstract}
Motto: «For as the more the rain pours down upon the earth, the more it softens the earth; so too the holy name of Christ, when it is invoked by us without thoughts, the more constantly we call upon it, the more it softens the earth of our heart, and fills it with joy and delight.» (Philokalia: Hesychius of Jerusalem)
\end{abstract}

\begin{abstract}
In the Eastern spiritual tradition the contemplation is made with the help of the Jesus prayer: "Lord Jesus Christ, Son of God, have mercy on me, the sinner", which becomes the prayer of the mind in its higher phase when words are no longer used, but the mind is occupied by this prayer together with the heart. This combination was the work of Hesychasm. The hesychast is one who devotes himself to the prayer of silence, to prayer that is stripped, so far as possible, of all images, words, and discursive thinking. Jesus Prayer has become linked to certain physical exercises, designed to assist concentration. Breathing was carefully regulated in time with the Prayer, and a particular bodily posture was recommended: head bowed, chin resting on the chest, eyes fixed on the place of the heart, but these exercises did not constitute the essence of prayer. The Jesus Prayer is not a magic talisman, nor do there exist any bodily exercises that will lead us automatically to union with God. From Sinai and Mount Athos the Jesus Prayer spread not only throughout the Greek East but also to the Slav world and then, through Paissy Velichkovsky, the apostle of the Jesus Prayer, to Romania. He was the first one to initiate this revival on the Slavic monachism, and it is instrumental to notice how this revival flourished on Romanian land. Despite what has been said about it (by some Western detractors), the practice of the heart prayer consists in giving way to the burning of the heart by grace, while at the same time, steadfastly watching over (nepsis) its inward purity. Thus, Jesus prayer becomes a medium for the union of the soul with God, due to the frequent practice of it, that would divert the soul from sinful deeds and draw it to an essential selfknowledge. The Name of Jesus, present in the human heart, communicates to it the power of deification. Shining through the heart, the light of the Name of Jesus illuminates all the universe.
\end{abstract}

Keywords: Jesus prayer, contemplation, union, mind, heart, grace, bodily posture, breathing, concentration, watchfulness, silence, Hesychasm, Mount Athos. 


\section{INTRODUCTION}

According to Orthodox Christian tradition it is possible, even in the present life for man to experience his deification as already taking place. In the Orthodox understanding Christianity signifies not merely an adherence to certain dogmas, not merely an exterior imitation of Christ through moral effort, but direct union with the living God, the total transformation of the human person by divine grace and glory - what the Greek Fathers termed "deification" or "divinization" (theosis, theopoiesis). In the words of St Basil the Great, man is nothing less than a creature that has received the order to become god: "He was made man that we might be made god."

St Gregory Palamas and the mystical theologians of Byzantium link this experience with the practice of continual prayer, whose aim is perpetual communion with God and hence the vision of divine light. This light is not a created medium nor a symbol of the divine glory, but an uncreated, natural energy deriving from God's essence, which, when manifested and united with man, constitutes for him the surest evidence of his deification and the highest form of his knowledge of God. ${ }^{1}$

Prayer is the uplifting of the mind and the feeling of the soul towards God. Through it the soul of the believer breathes in the mysterious atmosphere of life in Christ, it is our conversation with God. Prayer is the ascension of the mind and heart to God. Through it, the human soul ascends to God, but at the same time man descends into himself, into the depths of his inner being to meet God Who is present there, by divine grace, and thus experiencing the presence and work of God in his soul' life. The more intensely this prayer is made, the more sensitive the mysterious feeling of Christ in us becomes. In other words, as we detach ourselves from everything that belongs to the sensitive world, from everything that falls under the senses and is transient, to that extent we reach the contemplation of God in the depths of our soul.

This contemplation is made - in the Eastern spiritual tradition - with the help of the prayer of Jesus: "Lord Jesus Christ, Son of God, have mercy on me, a sinner", which becomes the prayer of the mind in its higher phase when words are no longer used, but the mind is occupied by this prayer together with heart ${ }^{2}$.

The Jesus Prayer ${ }^{3}$ also known as The Prayer of the heart is a short formulaic prayer esteemed and advocated especially within the Eastern churches. The prayer has been widely taught and discussed throughout the history of the Orthodox Church. The ancient and original form did not include the words "a sinner", which were added later. ${ }^{4}$ It is often repeated continually as a part of personal ascetic practice, its use being an integral part of the eremitic tradition of prayer known as Hesychasm. The prayer is particularly esteemed by the spiritual fathers of the hesychast tradition, as a method of cleaning and opening up the mind

\footnotetext{
${ }^{1}$ Georgios I. MANTZARIDIS, The deification of man. St Gregory Palamas and the Orthodox Tradition, trans. from the Greek by Liadain Sherrard, with a Foreword by Bishop Kallistos of Diokleia, St. Vladimir's Seminary Press, Crestwood, New York, 1984, p. 87.

${ }^{2}$ Vasile ANDRU, Isihasmul sau meșteșugul liniștirii (Hesychasm or the craft of tranquility), Herald Publishing House, București, 2008, p. 49.

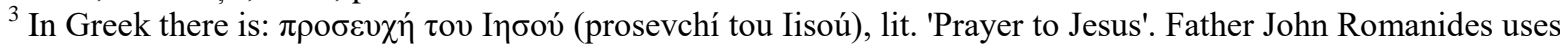

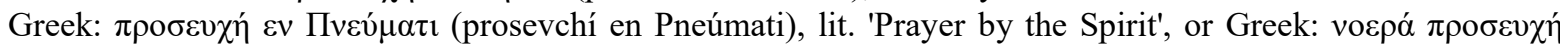
(noerá prosevchí), lit. 'noetic prayer'. Cf. Ioannis RoMANIDES, Jesus Christ-The Life of the World, translated from Greek, Archived from the original on 13 August 2018. Original: Romanides, John S. (5-9 February 1982). "Jesus Christ-The Life of the World". The Romans: Ancient, Medieval and Modern.

${ }^{4}$ Kallistos WARE, On the Prayer of Jesus by Ignatius Brianchaninov, 2006, pp. xxiii-xxiv.
} 
and after this the heart and bringing about firstly the Prayer of the Mind or more correctly

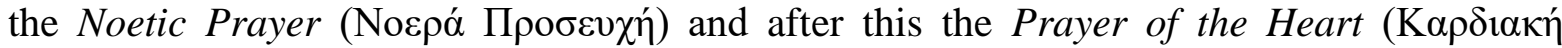

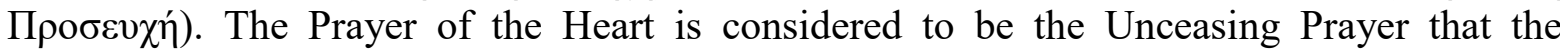
Apostle Paul advocates in the New Testament (1 Thes. 5:17). St. Theophan the Recluse regarded the Jesus Prayer stronger than all other prayers by virtue of the power of the Holy Name of Jesus.

\section{THE THEOLOGY OF GOD'S NAME}

The angel announced to Mary that her son would be called Jesus, for he would save men from their sins (Mt 1:21; cf. Lk 1:13). The name In $\sigma o v \sigma$ is the Greek transcription of the Hebrew Yeshua (Jesus), which is itself identical with Yehoshua (Joshua). The first of these two Hebrew words is a contraction of the second, intended to avoid the sequence of the vowels $o$ and $u$ which was repugnant to Jewish ears. The meaning of the name Yeshua, while clear in a general sense, is difficult to establish with any strict precision. The translation "savior" is more or less correct; more exactly the name signifies "salvation of Yahweh" or "Yahweh is salvation." Hence the ancient adage "nomen est omen" (lat. "the name is a sign", "the name speaks for itself"), the name expresses in a certain way the person and his destiny-applies to the angel's Annunciation concerning the name of the child.

Three texts from the New Testament are of special importance for the veneration of the name of Jesus. First of all (following what we believe to be the chronological order) there is St Paul's great text:

"God has given Him a name which is above all names, that at the name of Jesus every knee should bow, of those that are in heaven, on earth, and under the earth" (Phil 2:9-10).

Next, we have the solemn declaration from the Acts of the Apostles: "There is no other name under heaven given to men whereby we must be saved" (Acts 4:12). And finally, in the Gospel according to John we have the secret which Jesus reveals to his disciples:

"Hitherto you have not asked anything in My name ... Whatever you ask the Father in My name, He will give it you" (Jn 16:23-24).

The New Testament references to the name of Jesus are too numerous for us to pause at each one of them; but every student, with the help of a concordance, could do so with great profit. The Apocalypse furnishes an especially rich harvest. But it is above all the Acts of the Apostles which could be called the book of the name of Jesus. "In the name of Jesus" the good news is preached, converts believe, baptism is conferred, cures and other "signs" are accomplished, lives are risked and given. ${ }^{6}$ What is involved in this insistence on the name of Jesus is not just the employment of a magical formula, for no one can use this name effectively if he does not have an inner relationship with Jesus himself.

Unfortunately, the English expression "in the name of", like the Latin in nomine, is powerless to render the rich complexity of the Greek terms. In Latin and English, the phrase "in the name of Jesus" is more or less synonymous with "by the authority of Jesus"; "in the name of ..." becomes "by virtue of." This is to impoverish the New Testament Greek,

\footnotetext{
${ }^{5}$ A. Deissmann, "The Name of Jesus," in Mysterium Christi. Christological Studies by British and German Theologians, edited by G.K.A. Bell and D.A. Deissmann, London, 1930, pp. 3-27.

${ }^{6}$ W. Heitmuller, "Im Namen Jesu." Eine sprach - und religionsgeschichtliche Untersuchung zum Neuen Testament, speziell zur altchristlichen Taufe, in W. BOUSSET and H. GUNKEL, Forschungen zur Religion und Literatur des Alten und Neuen Testaments, Gottingen, 1903, I. Bd., 2. Heft, apud Archimandrite Lev GILLET, The Jesus Prayer, Revised edition with a foreword by Kallistos Ware, Bishop of Diokleia, St. Vladimir's Seminary Press, Crestwood, New York, 1987, pp. 27-28.
} 
stripping it of both its realism and its nuances. The Greek text, when referring to the name of

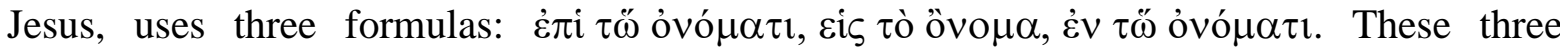
formulas are not equivalent, but each one expresses a special attitude toward the name. In

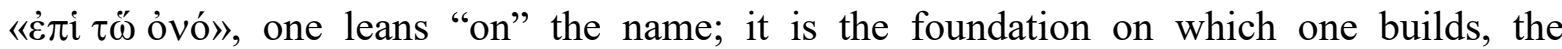
terminus a quo, the point of departure toward a subsequent action, the start of a new

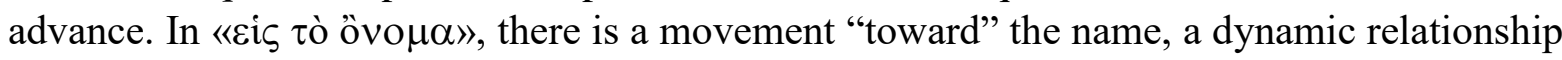
of finality which sees the name as the goal to be attained, the terminus ad quem. In

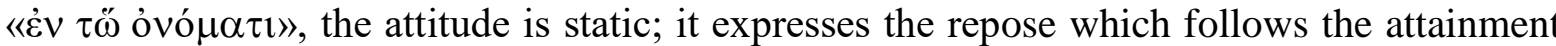
of the goal and a certain interiorization or immanence; our spirit is transported "into" the name, within the name, it is united to the name and makes its abode there. ${ }^{7}$ Father Ferdinand Prat has clearly indicated ${ }^{8}$ the differences between these three formulas, which could provide us with the plan of an entire way of prayer centering around the name of Jesus.

The Desert Fathers were well acquainted with the power of the name. St Athanasius reports that St Antony of Egypt (about 356) exorcised a devil by using the name of the Lord Jesus Christ. ${ }^{9}$ It does not seem that the Desert Fathers practiced the invocation of the name in an organized way. Among the Apophthegmata of the Fathers collected by Bousset, we find only two, of Syrian origin, on the name of Jesus. It is not much. But these monastic circles prepared the way for the Jesus Prayer in another manner. They gave to their private prayers the form of short aspirations. St Augustine wrote about this to Proba: "They say that the brethren in Egypt offer prayers that are frequent but very brief and suddenly shot forth." 10 . The Desert Fathers used the formula Kyrie eleison or the verse "O God, come to my aid; O Lord, make haste to help me" (Ps 70:1). It is God who is invoked; there is no special mention of the name of the Son. But suppose that one day this name is associated with ejaculatory prayer, that there is a meeting, a fusion, between name and aspiration-then we shall have the Jesus Prayer. ${ }^{11}$

\section{A SHORT HISTORY OF THE JESUS PRAYER}

This combination was the work of Hesychasm. Often this term has been given too limited an historical meaning, with the title "Hesychast" restricted to the Byzantine mystics of the 14th century, especially those of the Palamite school. In reality, Hesychasm is a spiritual tradition extending from the 5th to the 18 th century. ${ }^{12}$ The word hesychia was well established as a technical term in the first half of the $7^{\text {th }}$ century when St John Climacus devoted a chapter to it in his treatise The Ladder (Ladder 27, PG 88, cols. 1096-1101). But from the 5th century this tradition was already represented by such men as St Nilus of

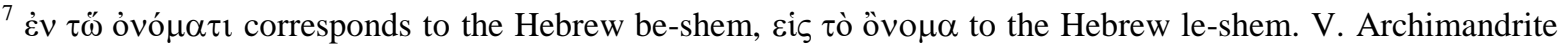
Lev GILLET, The Jesus Prayer, p. 27.

${ }^{8}$ Ferdinand PRAT, Jésus-Christ, sa vie, sa doctrine, son oeuvre, Paris, 1933, vol. II, note Z, pp. 564-567.

${ }^{9}$ St Athanasius, Life of St Antony 63, PG 26, col. 933A.

${ }^{10}$ St Augustine, Epist. CXXX, 20, PL 33, col. 501. These words of Augustine, "orationes ... quodammodo jaculates", have given rise to the expression "ejaculatory prayer." They were swift arrows shot toward the heart of God.

${ }^{11}$ M. VILLER and K. RAHNER, Aszese und Mystik in der Viiterzeit. Ein Abriss, Freiburg im Breisgau, 1939, ch. 12, par. 41. Cf. L. REGNAUlT, "La priere continuelle 'monologistos' dans la littérature apophtegmatique," in Irenikon 47, 1947, pp. 467-93.

12 See P. ADNES, "Hesychasme," in Dictionnaire de Spiritualité 7, 1968, cols. 381-99; I. HAUSHERR, in "Hésychasme et prière" (Orientalia Christiana Analecta 176: Rome, 1966), pp. 163-237. Cf. Kallistos WARE, "Silence in Prayer: The Meaning of Hesychia," in Basil Pennington (ed.), One Yet Two, Cistercian Studies Series 29: Kalamazoo, 1976, pp. 2247.
} 
Ancyra or the Sinaite, St Diadochus of Photike, and St John the Hesychast whose life was written by Cyril of Scythopolis. ${ }^{13}$

The Hesychast is one who devotes himself to the prayer of silence - to prayer that is stripped, so far as possible, of all images, words, and discursive thinking. Connected with this first question was another: what is the place of the body in prayer? Evagrius, like Origen, sometimes borrowed too heavily from Platonism: he wrote of prayer in intellectual terms, as an activity of the mind rather than of the whole person, and he seemed to allow no positive role to the human body in the process of redemption and deification. But the balance between mind and body is redressed in another ascetic writing, the Macarian Homilies. These Homilies of Macarius Magnes uphold a more Biblical idea of the human person - not a soul imprisoned in a body (as in Greek thought), but a single and united whole, soul and body together. Where Evagrius speaks of the mind or intellect (in Greek nous), he uses the Hebraic idea of the heart. The change of emphasis is significant, for the heart includes the whole person - not only intellect, but will, emotions, and even body. ${ }^{14}$

Using 'heart' in this Macarian sense, Orthodox often talk about 'prayer of the heart'. What does the phrase mean? When someone begins to pray, at first using the lips, the person must make a conscious intellectual effort in order to realize the meaning of what is said. But if that person perseveres, praying continually with recollection, intellect and heart become united: finding 'the place of the heart', the spirit acquires the power of 'dwelling in the heart', and so the prayer becomes 'prayer of the heart'. It becomes something not merely said by the lips, not merely thought by the mind, but offered spontaneously by the whole of one's being - lips, intellect, emotions, will, and body. The prayer fills the entire consciousness, and no longer has to be forced out, but says itself. Such prayer of the heart cannot be attained simply through our own efforts, but is a gift conferred by the grace of God. ${ }^{15}$

By the thirteenth century (if not before), the recitation of the Jesus Prayer had become linked to certain physical exercises, designed to assist concentration. Breathing was carefully regulated in time with the Prayer, and a particular bodily posture was recommended: head bowed, chin resting on the chest, eyes fixed on the place of the heart. ${ }^{16}$ This is often called 'the Hesychast method of prayer', but it should not be thought that for the Hesychasts these exercises constituted the essence of prayer. They were regarded, not as an end in themselves, but as a help to concentration - as an accessory useful to some, but not obligatory upon all. The Hesychasts knew that there can be no mechanical means of acquiring God's grace, and no techniques leading automatically to the mystical state. For the Hesychasts of Byzantium, the culmination of mystical experience was the vision of Divine

${ }^{13}$ Greek text, ed. E. Schwartz, Kyrillos von Skythopolis. Texte und Untersuchungen 49, 2: Leipzig, 1939, pp. 201-22; French translation by A.J. FESTUGIERE, Les moines d'Orient III, 2, Paris, 1963, pp. 13-34, apud apud Lev GILlET, The Jesus Prayer, p. 32.

${ }^{14}$ Cf. Norman RuSSELL, The Doctrine of Deification in the Greek Patristic Tradition, Oxford University Press, 2006, pp. 241 sq.

15 Timothy WARE (Bishop Kallistos of Diokleia), The Orthodox Church, Penguin Books, First published in 1963, Reprinted with revisions 1993, 1997, pp. 51-52.

16 There are interesting parallels between the Hesychast 'method' and Hindu Yoga or Muslim Dhikr; but the points of similarity must not be pressed too far. For details: Pr. Dr. Vasile PoP, Yoga și Isihasmul (Yoga and Hesychasm), Lidia Publishing House, Bucharest, 2003. 
and Uncreated Light. The works of St Symeon the New Theologian (949-1022), the greatest of the Byzantine mystics, are full of this 'Light mysticism'. ${ }^{17}$

St Gregory the Sinaite ( $\dagger 1346)$ represents, in the history of the Jesus Prayer the beginning of the Athonite phase. In his treatise On Stillness and the Two Methods of Prayer, he sets out the theological foundations of the mystical life in terms that the contemporary reader will find familiar and attractive ${ }^{18}$. Thus, the spiritual aspirant should devote himself to the Jesus Prayer in the morning. He will remain seated, with his head lowered. He will pronounce persistently the formula "Lord Jesus Christ, Son of God, have mercy on me", bringing both his soul and his intellect (nous) into play, immersing his intellect in his heart. Pronouncing the name of Jesus, he will be nourished by this divine name as by food ${ }^{19}$. He will apply himself to giving full meaning to each one of the words. Gregory allows a certain variety in the use of formulas: it is legitimate to alternate between "Lord Jesus Christ, have mercy on me" and "Son of God, have mercy on me", although one should not change the formula of invocation too frequently, since plants that are often transplanted do not take root. The Jesus Prayer allows us to reach the state described by St Paul: "It is no longer I that live, but Christ that lives in me" (cf. Gal 2:20). A place is also to be allowed for psalmody and reading. In fact, we know from Scripture that no one can say that Jesus is the Lord without a special inspiration from the Holy Spirit. One can say "in a pure and perfect way" the words "Lord Jesus" only in the Spirit (cf 1 Cor 12:3). It is better to refrain from using these words than to repeat them thoughtlessly like a child prattling away ${ }^{20}$. Among all the contributors in the history of the Jesus Prayer (of the Athonite phase), of a prominent role is, undoubtedly, St Gregory Palamas (1296-1359), who defended the hesychast saints in the famous dispute against the Calabrian monk Barlaam. St Gregory was not only the author of countless controversial writings, such as the Triads in Defense of the Holy Hesychasts, but also the ascetical and mystical author of such works as Three Chapters on Prayer and Purity of Heart, On the Passions and Virtues, and Decalogue of the Law according to Christ. ${ }^{21}$

Gregory did not discuss the Jesus Prayer specifically as a topic on its own, but it is taken for granted in almost all his writings, since he was replying to attacks directly aimed against it. The most original and most controversial aspect of his theology was his understanding of the "uncreated light" and his distinction between the divine essence and the divine energies. It was the Jesus Prayer that led Gregory to develop these ideas, since the vision of the divine light, of the "light of Tabor," was for Gregory the normal goal of Hesychast prayer and of the invocation of the name. It was in connection with these views of

\footnotetext{
${ }^{17}$ When he writes of his own experiences, he speaks again and again of the Divine Light: 'fire truly divine,' he calls it, 'fire uncreated and invisible, without beginning and immaterial'. The Hesychasts believed that this light which they experienced was identical with the Uncreated Light which the three disciples saw surrounding Jesus at His Transfiguration on Mount Tabor. Cf. Timothy WARE, The Orthodox Church, p. 52.

${ }^{18} \mathrm{Cf}$. the work of Dom Anselm STOLZ, Theologie de la mystique (Chevetogne, 1939), English translation by Aidan Williams, The Doctrine of Spiritual Perfection, St. Louis/London, 1938, which is in general very sympathetic to the Greek approach.

${ }^{19}$ Following out this line of thought, we might explore the eucharistic use of the name of Jesus, with the Jesus Prayer understood as a form of spiritual communion.

${ }^{20}$ Kallistos WARE, “The Jesus Prayer in St. Gregory of Sinai”, in: Eastern Churches Review, 4:1, 1972, pp. 3 22.

${ }^{21}$ A critical edition of Palamas' works is that under the general editorship of Professor Panagiotis K. Christou (3 vols.: Thessalonica, 1962-70). See also the edition of the Triads in Defense of the Holy Hesychasts by John Meyendorff, with critical Greek text and French translation (Spicilegium Sacrum Lovaniense 30-31: 2 vols., Louvain, 1959; 2nd ed., Louvain, 1973); selections in English translation are given in J. MEYENDORFF and N. GENDLE, Gregory Palamas: The Triads (The Classics of Western Spirituality: New York, 1983). s
} 
his on the uncreated light that violent conflict developed. We shall not enter into this controversy $^{22}$, but say only this: there has been a tendency to lose sight of the fact that the Hesychast theory of the vision of the divine light is concerned with the supernatural level and not with the normal psychological order. ${ }^{23}$ Gregory Palamas underwent the misfortune of all mystics who have interrupted their prayer so as to engage in disputes about it. It is true that he had been provoked by attacks which were often unjust and insulting ${ }^{24}$.

Emerging from this conflict, it is refreshing to read a work as full of peace, devotion, and a rare spiritual beauty as the Century of Kallistos and Ignatius Xanthopoulos. ${ }^{25}$ The Century constitutes a complete rule of life for the Hesychast. The center of this life is the Jesus Prayer. The authors distinguish here a twofold movement: a soaring ascent towards Jesus Christ in the first part of the prayer, "Lord Jesus Christ, Son of God . . ."; and a return to oneself, "have mercy on me." The rhythm of the respiration is to be associated with this twofold movement.

The repetition of the Jesus Prayer, the Xanthopouloi explain, leads to a feeling of warmth in the region of the heart. So powerful and overwhelming does this feeling sometimes become that the use of the full formula of the Prayer is rendered impossible. The more intense the experience of grace, the more concentrated grow the words of the invocation, until the hesychast is reduced to an almost inarticulate cry, "My Jesus!" ('Inбov $\mu$ ov):

\begin{abstract}
The holy energy wells up from the heart, seizing hold, as it were, of the heart's affection and stirring the intellect (vous) from its very depths. It becomes so closely united to the divine energy itself that it cries repeatedly: "My Jesus, my Jesus!" For as soon as the heart is opened up, this is all that the intellect cries out: "My Jesus!" The intellect is incapable of saying the whole formula, "Lord Jesus Christ, Son of God, have mercy on me", because of the frequent openings of the heart; and it can only say "My Jesus!" If anyone claims that while in this state he pronounces the whole prayer, he is deceiving himself; for when, as we have said, the intellect becomes attached to the divine energy and penetrates into the innermost depths of the heart, it is no longer able to cry out anything but "My Jesus!"26
\end{abstract}

The use of the short phrase "My Jesus!" on its own, as this passage makes clear, is not recommended by the Xanthopouloi as a normal practice, but it is something that happens

22 The Orthodox Church's understanding of the light of the Transfiguration is explained by Fr Georges FLOROVSKY, "The Mystery of the Light of Tabor" (in Russian), in Feuillets de saint Serge 3 (89) (Paris, 1935), and by Vladimir LossKY, In the Image and Likeness of God (Crestwood, 1974), pp. 45-69. Consult, also by LOSSKY, The Vision of God, 2nd ed., Crestwood, 1983, and The Mystical Theology of the Eastern Church, London, 1957.

${ }^{23}$ Moreover, this controversy, like the Filioque dispute, is the result largely of a misunderstanding between the two sides.

${ }^{24}$ But would not the best response to the offensive directed against the Jesus Prayer have been the peaceful influence radiating from the Prayer itself, its deeper exploration and, if so desired, a brief testimony based on personal experience, free from theories and polemic? Whatever the gains for theological speculation from the Hesychast dispute - if anything was gained - for pure spirituality there was only loss. See Archimandrite Lev GILLET, The Jesus Prayer, p. 61.

${ }^{25}$ Both sought to remain above all monks and contemplatives. They were members of the Monastery of the Xanthopouloi in Constantinople. The Kallistos of the Century is the Patriarch of Constantinople, St Kallistos II, who occupied the patriarchal see in 1397 for three months only (not to be confused with his namesake Patriarch Kallistos I).

${ }^{26}$ David Balfour (trans), Saint Gregory the Sinaite: Discourse on the Transfiguration, 147-8, apud Kallistos WARE, Bishop of Diokleia, A Fourteenth-Century Manual of Hesychast Prayer: The Century of St Kallistos and St Ignatios Xanthopoulos, Toronto, 1995, p. 18. 
to the hesychast only at exceptional moments, when he is engulfed by the conscious experience of "divine energy" and has approached close to a state of ecstasy.

As an accompaniment to the repetition of the Jesus Prayer, at any rate when it is said in its full form, the Xanthopouloi advocate the employment of a "physical technique" ( $\mu \varepsilon \dot{\theta} \theta \delta \delta \varsigma \phi \cup \sigma \imath \kappa \eta)$. Involving the control of the breathing and the search within oneself for the place of the heart ${ }^{27}$. In Gregory of Sinai, however, the regulation of the breathing is not just a preparatory technique to establish concentration before prayer itself begins, but it is intended to accompany the actual invocation of the holy name, although it is not explained precisely how the two are to be coordinated. ${ }^{28}$

Kallistos and Ignatios are at pains to make clear that "the physical technique", so far from constituting the essence of inner prayer, plays no more than a strictly subsidiary role; it is a useful accessory, but it is in no way obligatory. The Jesus Prayer is not a magic talisman, nor do there exist any bodily exercises that will lead us automatically to union with God. The Prayer is to be recited not mechanically but "with faith". Without God's grace our human efforts can achieve nothing:

Above all, the intellect can succeed in such an endeavor only with the help of divine grace, conferred upon us through faith by means of the single-phrased ( $\mu$ ovo $\lambda$ ó $1 \sigma \tau o \varsigma$ ), pure and undistracted invocation of our Lord Jesus Christ within the heart. Success cannot be achieved simply through the physical technique described above, involving inhalation through the nose and sitting in a quiet, dark place. Far from it! Such practices were devised by the divine fathers merely as a kind of aid, helping us to achieve mental concentration... But through them the mind also gains the power to pray unceasingly and cleanly without scattering. ${ }^{29}$

Father Dumitru Stăniloae, the great Romanian translator and commentator of Philokalia, explains this:
„The authors of this writing distinguish between the gathering of the mind in itself and the bringing of grace into the heart. The latter is helped by the unceasing calling of the name of Jesus. Only the former, that is, what man gives, is helped by regular breathing and sitting in a dark place. But through gathering in itself, the mind gains the power to pray incessantly. So that the coming of grace is only the indirect result of regular breathing and sitting in an obscure place. We have here something very distinct from the yogic methods, which have a purely natural character and do not seek to intensify the believer's relationship with the person of Jesus. The faithful praying man through interiorization is filled with the love of Christ; he does not simply focus on his own essence, which is ultimately part of the impersonal essence of everything., 30

\footnotetext{
${ }^{27}$ In the earliest Greek texts that speak clearly about this technique (dating from the late thirteenth or early fourteenth century) Pseudo-Symeon, On the Three Methods of Prayer, and Nikephoros the Hesychast, On Watchfulness and the Guarding of the Heart - the control of the breathing and the inner exploration are proposed as a preliminary exercise, which precedes the repetition of the Jesus Prayer rather than being simultaneous with it. Cf. Kallistos WARE, Bishop of Diokleia, A Fourteenth-Century Manual of Hesychast Prayer, p. 18.

${ }^{28}$ See K. WARE, "The Jesus Prayer in St Gregory of Sinai", 14-15; Balfour, Saint Gregory the Sinaite, 144. Gregory may intend the Jesus Prayer to be said while we hold our breath (i.e. between each inhalation and exhalation).

${ }_{29}$ Kallistos and Ignatius Xanthopoulos, The Century 24, in: Filocalia sau Culegere din scrierile Sfinților Părinți care arată cum se poate omul curăți, lumina și desăvârși (Philokalia or Collection from the writings of the Holy Fathers that show how man can be purified, enlighten and perfect), vol. 8, trans in Romanian, introduction, and notes by Father Dumitru Stăniloae, EIBMBOR, București, 1979, p. 65.

${ }^{30} \mathrm{Ibid}$, ft. 96, p. 66. For details, see: Dr. Alexandru-Corneliu ARION, Panteismul hinduist și învățătura creștină despre Dumnezeu (Hindu pantheism and the Christian teaching on God), Enciclopedică Publishing House, Bucharest, 2010, pp. 176-195; 420-432.
} 
From Mount Athos the Jesus Prayer spread not only throughout the Greek East but also to the Slav world. By the first half of the 15th century, if not before, it was being practiced in Russia. The Jesus Prayer is mentioned in an instruction for the training of young novices, dating from this period and emanating from the Monastery of the Trinity near Obnora, founded in 1389 by Paul, disciple of St Sergius of Radonezh. It is supposed to be said on the beads of the monastic rosary or prayer-rope. St Nil Sorsky (1433-1508), who had lived on Athos and came under the influence of Gregory the Sinaite, propagated the Jesus Prayer among the "monks across the Volga." In his works he presents it as an ascetic task, a "labor," and "action," and this way of conceiving it has never disappeared from Russian monasticism. The spiritual movement of the "Transvolga" monks, so deeply opposed to the institutionalism, which was to prevail in the Russian Church, had a natural affinity with Hesychasm and with the tendencies represented by the Jesus Prayer. ${ }^{31}$ In the 16th century we find the Prayer well established in Russia.

Paissy Velichkovsky (1722-94), of Russian origin, was the apostle of the Jesus Prayer in Romania, where he directed the monastery of Neamt. One of the great names in Orthodox monastic history, he had lived for a time on Athos. He translated the Philokalia into Church Slavonic under the title Dobrotolubie ("love of the beautiful" becomes in Slavonic "love of the good"). The Dobrotolubie ${ }^{32}$ had an even greater influence upon the Russian people than the Philokalia has had upon the Greeks. It was through this collection of texts that not only monks, but simple village people became familiar with the Fathers and with the Jesus Prayer. Paissy also wrote a letter to the "enemies and slanderers of the Jesus Prayer." In this he says:

\begin{abstract}
"One should know that this divine action was the constant occupation of our fathers who were filled with God. It shone as a sun in many places, in the desert and in cenobitic monasteries: on Sinai, in the sketes of Egypt, on Mount Nitria, in Jerusalem and in the neighboring monasteries, in a word in the whole of the East and later in Constantinople, on the Holy Mountain of Athos, on many islands, and in these last times, through the grace of Christ, also in Russia." 33
\end{abstract}

What is more than interesting represents the fact that before the edition of the Greek Philokalia in 1782, in the Romanian Principalities had already been available, on a large scale, Romanian translations from philokalic authors such as Peter Damaskin, Diadochos, Makarios, John of the Carpathians, Niketas Stethatos, Kallistos, Mark the Hermit and Ignatius Xanthopol. A 1004-pages translation into Romanian of Philokalia, published in 1800 at Neamt, confirms the tradition and the evolution of the local patristic texts, as it presents the first eighteen authors of the Venetian edition, with other texts added.

"It is worth mentioning the fact that the translators do not follow the Greek version from Venice strictly, but they use manuscripts they compiled themselves. This stands testimony to

\footnotetext{
${ }^{31}$ See G.A. Maloney, Russian Hesychasm. The Spirituality of Nil Sorskij, The Hague /Paris, 1973, especially pp. 134-44, 269-79. On Russian spirituality in general, see Pierre KovALEVSKY, St Sergius and Russian Spirituality, Crestwood, 1976; I. KologrIVov, Essai sur Ia saintete en Russie, Bruges, 1953; and above all I. SMOLITSCH, Moines de Ia sainte Russie, Paris, 1967. Cf. also G.P. FEDOTOV, A Treasury of Russian Spirituality, London, 1950; The Russian Religious Mind, 2 vols.: Cambridge, Mass., 1946, 1966; Elisabeth BEHR-SIGEL, Prière et sainteté dans l'Eglise russe, Paris, 1950: revised ed., Bellefontaine, 1982.

32 The work, comprising three parts, appeared in Moscow in 1793. This edition is very rare outside Russia, but there is a copy in the British Museum. Of the 36 texts in the Greek Philokalia, only 24 were included by Paissy. See further: "Un Moine de I'Eglise orthodoxe de Roumanie" (Fr André Scrima), "L'avimement philocalique dans l'Orthodoxie roumaine," in: Istina 5 (1958), pp. 295-328, 443-74. Cf. Blessed Paisius Velichkovsky, ed. St Herman of Alaska Brotherhood, Platina, 1976.

${ }^{33}$ Cf. Archimandrite Lev GILlET, The Jesus Prayer, p. 77.
} 
the love and seriousness the texts of the Fathers of the Church were being read in the Paisian monasteries." 34

What makes the Romanian contribution to the spreading of Philokalia remarkable was the fact that for the first time the texts of the vigilant Fathers, of the masters of the Jesus Prayer, were being translated into a language that was spoken, thus becoming accessible to readers not having special education. The Philokalia of 1782 "could not enjoy the success we would have expected" because of the difficult language, the patristic or Byzantine Greek. $^{35}$

The cardinal of Czech-origin, Tomáš Špidlík († 2010), one of the best connoisseurs of Orthodox Spiritual Tradition, mentioning the role of the Romanians in the Hesychastic current, asserts the following:

\section{"Paissy Velichkovki was the first one to initiate this revival on the Slavic monachism, and it is instrumental to notice how this revival flourished on Romanian land. The national and religious evolution of this nation is one of the most interesting in the history of modern Europe."36}

Particularly interesting is the fact that the motivation of the Romanian scholars in the Paisian community was predominantly spiritual, rather than cultural. The ascetic texts they translated were read to be experienced, for endeavors aimed at "changing the mind"

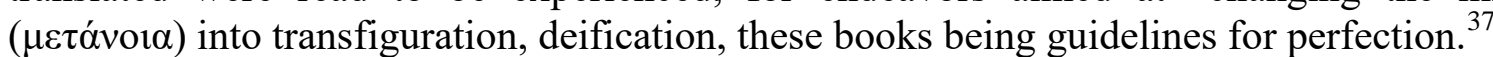

The great French Orthodox theologian, Olivier Clément, noticed that:

"The Romanian Principalities have been and still are a prodigious crossroads of cultures, in contact with the European West and East, as Romania is both Orthodox and Latin: fed on influences of Mount Athos and the Holy Places [...] and gained its unity and status of a modern country thanks to France, whose language is still spoken by its elite." 38

\section{Monological concentration}

The essence of the practice of silence is the monological repetition, the repetition of a single notion, of a formula of great conciseness: the hesychastic verse. St Varsanuphios warns: "We do not fight with thoughts but focus on something else (monologue repetition) and the thoughts disappear". The expression 'monologhistos', is used by St. John the Ladder for the Prayer of Jesus in its short form. By monologist repetition, the first positive result is to calm the mental agitation, to stop the "attacks" of the senses.

The second result is concentrating, fastening attention, fixing, and maintaining it into a point of existence. Thus, purification and emptying (gr. kenosis), premises of

\footnotetext{
34 Elia CitTERIO, „La scuola filocalica di Paisij Velichkovskij e la Filocalia di Nicodimo Aghiorita. Un confronto", in T. ŠPIDLÍk, K. WARE, E. LANne, M. van PARYS et al., Amore del Bello. Studi sulla Filocalia. Atti del «Simposio Internazionale sulla Filocalia», Qiqajon, Bose, 1991, pp. 189-191.

35 Virgil CÂNDEA, "Locul spiritualității românești în rê̂nnoirea isihastă” (The Place of the Romanian Spirituality in the Hesychastic Renewal), in: The Romanians in the Hesychastic Renewal. Studies on the Venerable Paisus from Neamt on the 200th Commemoration of His Death sale, Iași, Trinitas Publishing, 1997, pp. 27-30.

36 Thomaš ŠPIDLíK, Presentation, in: Cuviosul Paisie de la Neamț (Velicikovski), Autobiografia unui stareț (The Elder Paissy from Neamt,, Autobiography of a staretz), Foreword by Hieromonk Seraphim Rose, Introductory study by Elia Citterio, Edited by the deacon. Ioan I. Ică jr., Deisis, Sibiu, 1996, p. 65.

37 "These books were reserved to the prayer raisers, observers of ascesis and contemplation, not to the new modern intellectuals in this country who were wasting their stamina and time with Voltaire and Marmontel." See Virgil Cândea, The Place of the Romanian Spirituality in the Hesychastic Renewal, p. 36.

38 Olivier CLÉMENT, Rugăciunea lui Iisus (Jesus Prayer), Translation from French by Măriuca and Adrian Alexandrescu, Bucharest: The Biblical Institute Publishing, 1997, pp. 9-10.
} 
enlightenment occur, but also introspection or looking in or mirroring inside. This produces the expansion of consciousness, which increases alertness/watchfulness (Greek nepsis). Any deviation from alertness or vigilance (such as: trance, halving, vision, or paranormal effects) are errors and deceptions, they must be counteracted, restoring vigilance. ${ }^{39}$

The consecrated formula or verse repeated in the Prayer of the Mind is "Lord Jesus Christ, have mercy on me." The magnified formula is also widely practiced: "Lord Jesus Christ, Son of God, have mercy on me, a sinner." It has been said, "The hesychastic verse diminishes as it has been progressing." During practice, the hesychastic verse does not change. Keep the verse received from the guide as well as the way to synchronize it with the breath. The word "have mercy on me" is felt in the beginning as a plea, a request; in the middle, as contentment and gratitude; in the end, as love and communion. A distinction is made between all-time prayer (for guarding the mind) and hesychastic prayer (for changing the mind: metanoia). The former helps the latter. The first prefaces and relaunches the second. They both use the same verse, the same formula. It is just that the requirements and conditions for repeating the verse are different and the result is qualitatively different.

a) Prayer of all times can be said anytime and anywhere, on the street or in the subway, anytime, as a protection of the mind from worldly invasion, street aggression, inner and outer noise.

b) Hesychastic prayer, contemplation (theoria) is not practiced anytime and anywhere, but respects the requirements of mental climate, place, time and is done only with guidance.

The method has an obvious simplicity. But the effect is achieved only if you follow rules regarding sitting, synchronizing the verse with breathing, avoiding mental representations, lowering the mind into the heart. But also, through preparing the mind by forgiving everyone, preparing the body by fasting and proper nutrition. However, the biggest difficulty is the rule of perseverance: the decision to repeat daily, at the same time, without omitting a single day. To fulfill the rule of perseverance and all the others come naturally.

How long and how many times does the hesychastic verse entrusted to the devotee by the mentor repeat itself? There is no recipe. The Russian pilgrim repeated the verse "Lord Jesus Christ, have mercy on me" 3,000 times a day at the beginning; then, with the permission of the mentor, the number increased to 6,000 times a day, and even more, to 12,000 times a day. Then he noticed that the mind had entered a state of unceasing prayer, and no longer needed to "recite" the verse. ${ }^{40}$

\section{JESUS PRAYER, MEDIUM FOR THE UNION OF THE SOUL WITH GOD}

From the beginning the command to practice continued and perpetual prayer is at the center of awareness of the Church Fathers. As the Jesuit Irénée Hausherr notes, no Orthodox interpreter ever appears to have dared maintain that this command is an exaggeration; various opinions have been formulated only as regards the way in which continual prayer is to be understood. This was natural, since it is proved by experience that not only for those who are still "in the world," but also for those who abandon it and its cares, certain basic needs must be fulfilled: and this makes impossible the practice of incessant prayer as a

\footnotetext{
${ }^{39}$ Vasile ANDRU, Hesychasm or the craft of tranquility, p. 23.

${ }^{40}$ V. Pelerinul rus - Mărturisirile sincere către duhovnicul său ale unui pelerin rus cu privire la rugăciunea lui Iisus (The Russian Pilgrim - Sincere Confessions to a spiritual father of a Russian Pilgrim concerning Jesus Prayer), Translated from Russian by Archimandrite Paulin Lecca, Sophia Publisher, București, 1998.
} 
specific activity. ${ }^{41}$ Hesychasm is known in the West mainly because of the works of Fathers M. Jugie and I. Hausherr, very learned authors, but who, unfortunately, show a strange zeal in defaming the object of their studies. Pausing especially at the external technique of the prayer of the mind, these modern critics strive in their writings to ridicule a practice of spiritual life that is foreign to them. They portray the hesychasts as ignorant and grossly materialistic monks, imagining that the soul is in the navel and that our breath embraces the Spirit of God; the prayer would therefore be a matter of holding our breath and fixing our gaze on the navel, uttering the same words incessantly, in order to fall into an ecstatic state. But this would ultimately be a purely mechanical process, used in order to cause a certain state of mind. In reality, the prayer of the mind, as presented in the ascetic tradition of the East, has nothing in common with this caricature. It involves - it is true! - a bodily side, certain procedures which refer to the mastery of the breath, to the position of the body during prayer, to the rhythm of prayer, but this external discipline has only one purpose: to facilitate concentration. ${ }^{42}$

Far from mechanizing the inner life, on the contrary, it serves for liberation, for its return to contemplation, permanently removing from the realm of the heart any touch of sin, any thought or image that comes from outside, and this through the power of the holy name of Jesus. St Theophan the Recluse, the famous teacher of the spiritual life and great Russian ascetic writer of the nineteenth century, expressed himself on the purpose of the prayer of the mind in such manner:

\begin{abstract}
"Is being sought, he says, the fire of grace that falls in the heart ... When this spark of God (i.e. the holy grace) is in the heart, the prayer of Jesus revives it and turns it into flame. However, it does not produce this spark, but only gives the possibility to receive it by gathering thoughts, and by directing the soul before the Face of the Lord. The main point is to stand before God, crying out to Him from the bottom of your heart. So must proceed all who seek the fire of grace; as for the words or positions of the body during prayer, they have only a secondary meaning. God looks at the heart." ${ }^{43}$
\end{abstract}

Therefore, despite what has been said about it, the practice of the prayer of the heart, specific to the Eastern Christianity, consists in giving way to the burning of the heart by grace, while at the same time, steadfastly watching over (nepsis) its inward purity.

Far from seeking ecstasy or enthusiasm state, the mind in prayer must refrain from giving the deity any image:

\begin{abstract}
"Desiring to see the face of the heavenly Father," says St Nilus of Sinai, "do not strive to discern any image or face during your prayer. Flee from the desire to see in a sensitive form the angels, the (celestial) powers, or Christ; otherwise you take the risk of going mad, mistaking the wolf for a shepherd and glorifying the devils in God's place ... the beginning of wandering is in the will of the mind that tries to grasp the deity in an image or face." 44
\end{abstract}

\footnotetext{
${ }^{41}$ Georgios I. MANTZARIDIS, The deification of man. St Gregory Palamas and the Orthodox Tradition, p. 90.

42 See art. Dr. G. WUNDERLE, „La technique psychologique de l'hesychasme byzantin“, in Etudes Carmélitaines, Oct. 1938, pp. 61-67. Cf. also the important hesychastic source, Century of Kallistos and Ignatius, published in German trans. by P. Ammann, Wurzburg, 1938. These two articles mark the beginning of more in-depth and impartial studies on hesychasm, unfortunately not rightly appreciated even today in the West.

${ }^{43}$ Bishop THEOPHAN the Recluse, Writings, vol. V, n. 911 (in Russian), apud Vladimir LosSKY, Teologia mistică a Bisericii de Răsărit (The Mystical Theology of the Eastern Church), Preface by Prof. Dr. Dumitru Stăniloae, Introductory study and French translation by Vasile Răducă, Humanitas, Bucharest, 2010, p. 222.

${ }^{44}$ St NILUS of Sinai, De oratione, cap. 114-116, P.G., vol. 79, col. 1192-1193, apud Vladimir LOSSKY, The Mystical Theology of the Eastern Church, p. 223.
} 
Prayer is the "result" of thought and of the heart that is fully aware. It could be defined as man's conscious effort to communicate with God so that he could unify with Him. $^{45}$ But the hardest thing for man is to descend the mind into the heart, seen as the focus of the spiritual life. For as it is said in the famous Russian book on Jesus Prayer, called Sbornik:

\begin{abstract}
"When the mind is in the heart, then the union of the mind with the heart takes place, which presupposes the integrity of our spiritual organism... The union of the mind with the heart is the union of the spiritual thoughts of the mind with the spiritual feelings of the heart. The heart is the inner man, or spirit, where we are conscious of ourselves, where the conscience is, the idea of God with the feeling of our hanging on Him, as well as the whole spiritual life with its eternal price" ${ }^{46}$.
\end{abstract}

The purpose of the prayer of the mind is union with God, Who is Spirit, and, for this reason, that union can be called spiritual. Frequent repetition of prayer will necessarily bring out the habit and will transform it into the second nature, which will eventually attract both the mind and heart into the proper state. If man were to fulfill, without any escape from sight, this one divine commandment concerning unceasing prayer, then he would fulfill all the commandments by the single one, for if he were to perform the prayer continually, at any time, and in any occupation or things, if he secretly called upon the divine name of Jesus Christ- although at first he would do so without any warmth and without zeal, but only by force-, yet on this particular time he would no longer have the respite for the felt and sinful pleasures. The frequent practice of prayer would divert the soul from sinful deeds and draw it to an essential self-knowledge, to union with God! $!^{47}$

\title{
CONCLUSION
}

The history of the "Jesus Prayer" - a technical term in Byzantine spirituality which designates the invocation of the name Jesus, whether alone or inserted into a more or less extended formula - has yet to be recounted in a comprehensive way, although there are various studies on points of detail. The subject has an interest that is more than purely historical. While the practice of the Prayer goes back to early times, it still remains very much alive today in the Christian East. It is not generally mentioned in standard treatises on the "ways of prayer," and yet it is more ancient and more widespread than the methods analyzed in the classic manuals. The famous Romanian writer and theologian, Nichifor Crainic, has written that the Jesus Prayer is the "heart of Orthodoxy." 48 The Uniates also use it; Latins have taken an interest in it; there are Anglicans and Protestants of our day who

\footnotetext{
${ }^{45}$ In fact, prayer is man's talking and communicating with God. It is the soul's life. As the body is alive as long as it breathes and when breathing ceases life ceases, this is what happens with the soul of the man who does not pray, that person is not alive, and the Christian cannot achieve eternal life, as prayer is the key to God's Kingdom. See Rev. PhD Liviu PETCU, "The Reception of Hesychasm in the Romanian Culture", in International Journal of Orthodox Theology, 7:1 (2016), p. 78.

${ }^{46}$ Sbornicul. Culegere despre rugăciunea lui Iisus (Sbornik. Collection on the Jesus prayer), vol. I: Lucrarea minții (The work of the mind), trans. in Romanian by Fr. Gheorghe Roșca, Episcopia Ortodoxă Alba Iulia (Alba Iulia Orthodox Episcopate), 1994, cap. 148-149, pp. 102-103.

${ }^{47}$ Cf. Sbornik, pp. 241 sq.

${ }^{48}$ N. CRAINIC, "Das Jesus gebet," an article translated from the Romanian by W. Biemel in Zeitschrift fur Kirchengeschichte 60 (1941), pp. 341-353. The article is conspicuously lacking in critical judgment: the author attributes the invention of the Jesus Prayer to the Blessed Virgin Mary. This might be true in some mystical sense but cannot be affirmed as a fact of history.
} 
fervently follow this method of prayer; it is our common patrimony. More than a private devotion, it borders on the realm of liturgy and even penetrates it. ${ }^{49}$

Gregory Palamas rightly considered blessed those who become accustomed to this heavenly activity, for by it they conquer all the temptations of the evil spirits, just as David conquered the proud Goliath. In this way they quench the disorderly desires of the flesh.

\begin{abstract}
"This mental prayer is the light enlightening man's soul and enkindling his heart with the fire of love towards God. It is the chain uniting God to man and man to God. Oh, there is nothing that can compare to the grace of mental prayer! It makes man a constant converser with God. O truly wondrous and most wondrous work! In the body you are with people, but mentally you converse with God"
\end{abstract}

St Maximus the Confessor, Symeon the New Theologian, Gregory of Sinai, and Gregory Palamas figure prominently in the Philokalia. Their teaching on deification through participation in the divine light became familiar to a wide monastic readership. St Seraphim of Sarov, the best-known of the Russian nineteenth-century mystics, was seen by more than one of his disciples transfigured by an intense light. 'Remember the transfiguration of the Lord on Mount Tabor', the staretz is reported to have said.

\begin{abstract}
"When Moses and Elijah came to him then, in order to hide the shining light of divine grace which blinded the disciples, a cloud, it is said, overshadowed them. In this manner the grace of the All-Holy Spirit of God manifests itself in an indescribable light to all those in whom God manifests its action". 51
\end{abstract}

In more recent times a remarkable testimony to the continuity of the same teaching and experience of transfiguration has been borne by St Silouan of Mount Athos and his disciple, Archimandrite Sophrony. ${ }^{52}$ If the repentant sinner perseveres and 'consciously abides in the Holy Spirit', says Sophrony, 'the vision of immortal glory and undying light is vouchsafed to him' and he becomes a participant in the life of Christ, having become "without beginning" (not in essence, but by grace) ${ }^{, 53}$ Such perseverance is directed not towards the pursuit of mystical experience, but to making Christ fully effective in the Christian's life. ${ }^{54}$

This prayer is particularly useful in modern times when the modern man does not have time to pray. If we start practicing this prayer, we shall discover we have more time

\footnotetext{
${ }^{49}$ Archimandrite Lev GILLET, The Jesus Prayer, p. 21.

${ }^{50}$ St GREGORY Palamas, in: The way of Pilgrim, fn. 26, p. 147.

${ }^{51}$ Sergius BolshaKOFF, Russian Mystics, CSS 26. Kalamazoo, Mich.: Cistercian Publications, 1977, p. 135.

52 Archimandrite Sophrony came to England in 1959 and founded an Orthodox monastery at Tolleshunt Knights in Essex. His books on St Silouan have circulated widely. Less well known is his spiritual testimony (Sophrony 1988) in which he vividly describes his own experience of uncreated light. Interestingly, this is balanced by the equally powerful experience of the mind's descent into hell. See Norman RUSSELL, The Doctrine of Deification in the Greek Patristic Tradition, p. 311.

53 Archimandrite SopHrONy (Sakharov), We Shall See Him as He Is, Trans. Rosemary Edmonds. Tolleshunt Knights: Stavropegic Monastery of St John the Baptist, 1988, p. 45.

54 A curious early twentieth-century aberration in the development of the hesychastic tradition may be mentioned here, the heresy of the name-worshippers (Imiaslavie), which arose from treating the name itself of God as a separate hypostasis. That the Orthodox Church pronounced it a heresy underlines its opposition to the multiplication of hypostases in the Godhead. Imiaslavie (Russian: Имяславие, literally praising the name) or Imiabozhie (Имябожие) also referred to as onomatodoxy (name-worshippers), is a dogmatic movement which asserts that the Name of God is God Himself. Although it was condemned by the Russian Orthodox Church in 1913, it is still promoted by some contemporary Russian writers. For details, see: http://onimyaslavie.blogspot.com/search/label/Imiaslavie
} 
available for prayer than we had ever imagined. ${ }^{55}$ The man strengthens spiritually by reciting Jesus's Name as there is no other being greater in Heaven or on the Earth. About the outstanding importance of heart prayer significantly confessed (to a brother) a Romanian Elder, Father Ghervasie Gașpar from Sihăstria Monastery († 1948): "I am sorry that I must leave this body and have not learned better the Jesus Prayer! In all my trouble this was my only solace." 56 Orthodox believe that the power of God is present in the Name of Jesus, so that the invocation of this Divine Name acts as an effective sign of God's action, endowed with sacramental grace.

"The Name of Jesus, present in the human heart, communicates to it the power of deification. Shining through the heart, the light of the Name of Jesus illuminates all the universe". 57

Alike to those who recite it continually and to those who only employ it occasionally, the Jesus Prayer proves a great source of reassurance and joy. To quote the celebrated Pilgrim:

"And that is how I go about now, and ceaselessly repeat the Jesus Prayer, which is more precious and sweeter to me than anything in the world. At times I do as much as forty-three or forty-four miles a day, and do not feel that I am walking at all. I am aware only of the fact that I am saying my Prayer. When the bitter cold pierces me, I begin to say my Prayer more earnestly, and I quickly become warm all over. When hunger begins to overcome me, I call more often on the Name of Jesus, and I forget my wish for food. When I fall ill and get rheumatism in my back and legs, I fix my thoughts on the Prayer, and do not notice the pain. If anyone harms me I have only to think, 'How sweet is the Jesus Prayer!' and the injury and the anger alike pass away and I forget it all. I thank God that I now understand the meaning of those words I heard in the Epistle - Pray without ceasing (I Thessalonians 5:17)." (The Way of a Pilgrim, R. M. French, pp. 17-18)

So, whenever we say "Jesus," we rest in a plentitude and totality that can no longer be taken from us. The name of Jesus then becomes a bearer of the whole Christ. It brings us into His total presence. The Jesus prayer helps to lift the whole life, body and soul, to a level where the senses and imagination no longer seek for outward change or stimulation, where all is subordinated to the one aim of centering the whole attention of body and soul upon God, in the sense that the world is sought and known in the beauty of God, not God in the beauty of the world (Mother Maria of Normanby, Swiss Orthodox nun). At all times and in every place it is fitting to call upon the name of God; for thus we 'beat the enemies,' says St. John of the Ladder, 'with the name of Jesus,' and a stronger weapon you will not find either in heaven or earth.

The hesychast, that is the one who devotes himself to the prayer of silence, senses it like the tremendous silences that surround and elevate us at the end of Beethoven's Ninth Symphony or the Bach' Mass in B Minor. It is a silence that not only rings with the various kinds of music that are consummated in it but seems, momentarily, to call down, to embody and enshrine the Divine presence itself. Only the highest art of prayer informed by the deepest spiritual intelligence and love could lead us to a place where all expression and feeling dissolve in wonder, and wherein one feels and thinks with Jesus' heart and mind.

\footnotetext{
55 Olivier ClÉMENT, Rugăciunea lui Iisus (Jesus Prayer), Translation from French by Măriuca and Adrian Alexandrescu, Bucharest, Biblical Institute Publishing, 1997, p. 9.

${ }^{56}$ See Ioanichie BĂLAN, Patericul românesc (Romanian Patericon), 4th edition, Roman Episcopate Publishing, Roman, 2001, p. 215.

${ }^{57}$ Sergius Bulgakov, The Orthodox Church, Centenary Press, London, 1935, pp. 170-171.
} 


\section{BIBLIOGRAPHY}

[1] Andru, Vasile, Isihasmul sau meșteșugul liniștirii (Hesychasm or the craft of tranquility), Herald Publishing House, București, 2008.

[2] Arion, Alexandru-Corneliu, Panteismul hinduist și învățătura creștină despre Dumnezeu (Hindu pantheism and the Christian teaching on God), Enciclopedică Publishing House, Bucharest, 2010.

[3] Bălan, Ioanichie, Patericul românesc (Romanian Patericon), 4th edition, Roman Episcopate Publishing, Roman, 2001.

[4] Behr-Sigel, Elisabeth, Prière et sainteté dans l'Eglise russe, Paris, 1950: revised ed., Bellefontaine, 1982.

[5] Bolshakoff, Sergius, Russian Mystics, CSS 26. Kalamazoo, Mich.: Cistercian Publications, 1977.

[6] Bulgakov, Sergius, The Orthodox Church, Centenary Press, London, 1935.

[7] Cândea, Virgil, "Locul spiritualității românești în reînnoirea isihastă" (The Place of the Romanian Spirituality in the Hesychastic Renewal), in: The Romanians in the Hesychastic Renewal. Studies on the Venerable Paisus from Neamt on the 200th Commemoration of His Death sale, Iași, Trinitas Publishing, 1997.

[8] Citterio, Elia, „La scuola filocalica di Paisij Velichkovskij e la Filocalia di Nicodimo Aghiorita. Un confronto", in T. Špidlík, K. Ware, E. Lanne, M. van Parys et al., Amore del Bello. Studi sulla Filocalia. Atti del «Simposio Internazionale sulla Filocalia», Qiqajon, Bose, 1991.

[9] Clément, Olivier, Rugăciunea lui Iisus (Jesus Prayer), Translation from French by Măriuca and Adrian Alexandrescu, Bucharest: The Biblical Institute Publishing, 1997.

[10] Crainic, Nichifor, "Das Jesus gebet," an article translated from the Romanian by W. Biemel in Zeitschrift fur Kirchengeschichte 60 (1941).

[11] Deissmann, A., "The Name of Jesus," in Mysterium Christi. Christological Studies by British and German Theologians, edited by G.K.A. Bell and D.A. Deissmann, London, 1930.

[12] Florovsky, Fr Georges, "The Mystery of the Light of Tabor" (in Russian), in Feuillets de saint Serge 3 (89), Paris, 1935.

[13] Gillet, Archimandrite Lev, The Jesus Prayer, Revised edition with a foreword by Kallistos Ware, Bishop of Diokleia, St. Vladimir's Seminary Press, Crestwood, New York, 1987.

[14] Hausherr, I., in "Hésychasme et prière", Orientalia Christiana Analecta 176, Rome, 1966.

[15] Kallistos and Ignatius Xanthopoulos, The Century, in: Filocalia sau Culegere din scrierile Sfinților Părinți care arată cum se poate omul curăți, lumina și desăvârși (Philokalia or Collection from the writings of the Holy Fathers that show how man can be purified, enlighten and perfect), vol. 8, trans in Romanian, introduction, and notes by Father Dumitru Stăniloae, EIBMBOR, București, 1979.

[16] Kologrivov, I., Essai sur Ia saintete en Russie, Bruges, 1953.

[17] Kovalevsky, Pierre, St Sergius and Russian Spirituality, Crestwood, 1976.

[18] Lossky, Vladimir, Teologia mistică a Bisericii de Răsărit (The Mystical Theology of the Eastern Church), Preface by Prof. Dr. Dumitru Stăniloae, Introductory study and French translation by Vasile Răducă, Humanitas, Bucharest, 2010.

[19] Maloney, G.A., Russian Hesychasm. The Spirituality of Nil Sorskij, The Hague /Paris, 1973.

[20] Mantzaridis, Georgios I., The deification of man. St Gregory Palamas and the Orthodox Tradition, trans. from the Greek by Liadain Sherrard, with a Foreword by Bishop Kallistos of Diokleia, St. Vladimir's Seminary Press, Crestwood, New York, 1984.

[21] Meyendorff, J. and Gendle, N., Gregory Palamas: The Triads, The Classics of Western Spirituality: New York, 1983.

[22] Nilus, of Sinai, St, De oratione, cap. 114-116, P.G., vol. 79, col. 1192-1193.

[23] Pelerinul rus - Mărturisirile sincere către duhovnicul său ale unui pelerin rus cu privire la rugăciunea lui Iisus (The Russian Pilgrim - Sincere Confessions to a spiritual father of a Russian Pilgrim concerning Jesus Prayer), Translated from Russian by Archimandrite Paulin Lecca, Sophia, București, 1998.

[24] Petcu, Rev. PhD Liviu, "The Reception of Hesychasm in the Romanian Culture", in International Journal of Orthodox Theology, 7:1 (2016).

[25] Pop, Pr. Dr. Vasile, Yoga și Isihasmul (Yoga and Hesychasm), Lidia Publishing House, Bucharest, 2003.

[26] Prat, Ferdinand, Jésus-Christ, sa vie, sa doctrine, son oeuvre, Paris, 1933, vol. II.

[27] Regnault, L., "La priere continuelle 'monologistos' dans la littérature apophtegmatique," in Irenikon 47, 1947. 
[28] Romanides, Ioannis, Jesus Christ-The Life of the World, translated from Greek, Archived from the original on 13 August 2018.

[29] Russell, Norman, The Doctrine of Deification in the Greek Patristic Tradition, Oxford University Press, 2006.

[30] Sakharov, Archimandrite Sophrony, (We Shall See Him as He Is, Trans. Rosemary Edmonds. Tolleshunt Knights: Stavropegic Monastery of St John the Baptist, 1988.

[31] Sbornicul. Culegere despre rugăciunea lui Iisus (Sbornik. Collection on the Jesus prayer), vol. I: Lucrarea minții (The work of the mind), trans. in Romanian by Fr. Gheorghe Roșca, Episcopia Ortodoxă Alba Iulia (Alba Iulia Orthodox Episcopate), 1994.

[32] Scrima, Fr André, "Un Moine de I'Eglise orthodoxe de Roumanie" - "L'avimement philocalique dans l'Orthodoxie roumaine," in: Istina 5 (1958).

[33] Smolitsch, I., Moines de Ia sainte Russie, Paris, 1967.

[34] Špidlík, Thomaš, Presentation, in: Cuviosul Paisie de la Neamț (Velicikovski), Autobiografia unui stareț (The Elder Paissy from Neamț, Autobiography of a staretz), Foreword by Hieromonk Seraphim Rose, Introductory study by Elia Citterio, Edited by the deacon. Ioan I. Ică jr., Deisis, Sibiu, 1996.

[35] Stolz, Dom Anselm, Theologie de la mystique (Chevetogne, 1939), English translation by Aidan Williams, The Doctrine of Spiritual Perfection, St. Louis/London, 1938.

[36] Ware, Kallistos (Bishop of Diokleia), A Fourteenth-Century Manual of Hesychast Prayer: The Century of St Kallistos and St Ignatios Xanthopoulos, Toronto, 1995.

[37] — . "Silence in Prayer: The Meaning of Hesychia," in Basil Pennington (ed.), One Yet Two, Cistercian Studies Series 29: Kalamazoo, 1976.

[38] — _ "The Jesus Prayer in St. Gregory of Sinai”, in: Eastern Churches Review, 4:1, 1972.

[39] —. The Orthodox Church, Penguin Books, First published in 1963.

[40] Wunderle, Dr. G., „La technique psychologique de l'hesychasme byzantin“, in Etudes Carmélitaines, 1938. 